\title{
Demonstrationer i Finland
}

\author{
Risto Alapuro
}

SAMMANDRAG: Fram till 1960-talet var arbetardemonstrationer och studentdemonstrationer de två betydande demonstrationstraditionerna i Finland. Risto Alapuro visar hur båda traditionerna i en europeisk jämförelse framstår som fredliga och disciplinerade, vilket kan förklaras av dominansen av sammanslutningar och deras handlingsformer $\mathrm{i}$ den finska repertoaren av kollektiva handlingar. Till och med studentdemonstrationerna på 1960-talet präglades av ordning. De viktigaste undantagen sammanföll med kriser mellan Finland och Ryssland eller Sovjetunionen: det stormiga året 1917 och åren närmast efter andra världskriget. Under dessa perioder ökade icke-socialisternas upplevelse av oordning genom den verkliga eller tillskrivna kopplingen av demonstrationer till den östra grannen, något som oundvikligen accentuerade spänningen mellan föreställningarna om ordning och oordning. Under de senaste årtiondena har traditionen blivit mer diversifierad, med inspiration från den västeuropeiska repertoaren, men dess ordnade karaktär har inte försvunnit.

NYCKELORD: demonstrationer; sociala rörelser; kollektiv handling; arbetarrörelse; studenter; Finland; Ryssland.

PUBLICERINGSHISTORIK: Originalpublicering.

RISTO ALAPURO är professor emeritus i sociologi, senast vid Helsingfors universitet. E-POSTADRESS: risto.alapuro@helsinki.fi

FÖRSLAG PÅ KÄLLANGIVELSE:

Alapuro, Risto (2017) "Demonstrationer i Finland”, i Arkiv. Tidskrift för samhällsanalys, nr 8, s. 87-II2.

DOI: https://doi.org/IO.I3068/2000-6217.8.4

(C) Risto Alapuro/Arkiv förlag \& tidskrift 2017 (publicerad 8 december 20I7)

Artikeln distribueras enligt en upphovsrättslicens från Creative Commons:

Erkännande-Ickekommersiell-IngaBearbetningar 3.0 Unported, som medger fri ickekommersiell användning och spridning i oförändrat skick så länge källan anges. 
Arkiv. Tidskrift för samhällsanalys är en sakkunniggranskad vetenskaplig tidskrift för samhällsvetenskap och historia. Samtliga artiklar publiceras fritt tillgängliga på:

$$
\text { www.tidskriftenarkiv.se }
$$

Beständig länk, DOI: https://doi.org/IO.13068/2000-62I7

Den här artikeln finns tillgänglig i följande format:

PDF \& HTML: via beständig länk, DOI: https://doi.org/IO.I3068/2000-62I7.8.4 EPUB: ingår i e-boksutgåva av numret, ISBN: 978 9I 79242909

TRYCK: ingår i bokutgåva av numret, ISBN: 978 9I 7924 29I 6

Grafisk utformning och sidnumrering är identisk i pdf och tryck.

Samtliga artiklar i nr 8 (20I7) nås via beständig länk, DOI: https://doi.org/I0.13068/2000-6217.8

Arkiv. Tidskrift för samhällsanalys ISSN: 2000-62I7 (för elektronisk resurs) ISSN: 2000-6225 (för tryckta nummer)

ges ut av

Stiftelsen Arkiv för främjande och spridning av samhällsvetenskaplig och historisk forskning

genom

Arkiv förlag \& tidskrift

Box 1559 SE-22I OI Lund

BESÖK: L Gråbrödersg 3 c, ipg TEL: 046-I3 3920

ARKIV FÖRLAG: arkiv@arkiv.nu·www.arkiv.nu

TIDSKRIFTEN ARKIV: red@tidskriftenarkiv.se.www.tidskriftenarkiv.se

ANSVARIg UTGIVARE \& CHEFREDAKTÖR: Sven Hort

Administrativ Redaktör: David Lindberg Redaktörer: Paavo Bergman, Per Dannefjord, Lisa Kings,

Zhanna Kravchenko, Anna-Maria Sarstrand Marekovic 


\section{Demonstrationer i Finland}

\section{RISTO ALAPURO}

Det sätt på vilket massdemonstrationer genomförs vittnar om arten av det förhållande som råder mellan staten och (det civila) samhället i ett givet land. Denna idé antyds i Göran Therborns beskrivning av den "flyktiga massan" vid den ena polen och den "bestående sammanslutningen" vid den andra polen av ett "handlandets kontinuum" i Europa. Dessa båda former av kollektiv handling är alternativa sätt att höja rösten mot "rådande makter": den förra genom den "direkta masshandlingens högtalare", den senare genom "att representanter möts vid ett förhandlingsbord" (1996: 400, något ändrad översättning). Som de tydligaste exemplen framträder å ena sidan de sammanslutningsorienterade nordiska länderna och å andra sidan de sydeuropeiska länderna (inklusive Frankrike) som är mer orienterade mot direkt aktion. ${ }^{\mathrm{I}}$

En fråga man kan ställa om demonstrationer i det här perspektivet är vilken roll som de eller massaktioner mer generellt spelar i en kontext

I. Göran Therborn skriver i en not i sin Europa, det moderna. Sambällen i öst och väst, nord och syd 1945-2000 (1996: 335, not 15): "Jag vill också erkänna min tacksamhet för en hittills opublicerad studie av den finska förstamajtraditionen av min vän och kollega Risto Alapuro." Studien fullbordades aldrig i den formen; jag hoppas att den här artikeln delvis kommer att fylla luckan.

En tidigare version av den här artikeln har publicerats på engelska som "Finnish Demonstrations as Confrontations" i Gunnar Olofsson \& Sven Hort (red.), Class, Sex and Revolutions. Göran Therborn - A Critical Appraisal, Arkiv förlag 2016. 
dominerad av sammanslutningar och deras handlingar. Svaret är inte självklart. Är de fredliga, disciplinerade och speglar de dominerande handlingsformer som har sammanslutningen som bas eller är de, i den mån de anammas, exceptionellt konfrontativa beroende på deras motstånd mot den rådande repertoaren av kollektiv handling? Hur varierar formerna och graden av konflikt beroende på skiftningarna i statens kontroll?

I denna artikel begrundar jag dessa frågor genom att titta på finska demonstrationer - främst under I900-talet - och ge tillfälliga komparativa kommentarer om Frankrike, ett typiskt fall i andra ändan av den kollektiva handlingens kontinuum. Här är framför allt arbetardemonstrationer talande av den enkla anledningen att det europeiska I900-talet i ett socialhistoriskt perspektiv var, för att citera Therborn, "arbetarklassens tidsålder" i sådan grad att arbetarrörelsen blev "Europas gåva till världen" (2014: 67, 92). En annan viktig grupp i den finska demonstrationshistorien har varit universitetsstudenterna, och då inte bara tack vare upproren 1968 som Therborn frammanar som de mest dramatiska av de nya eller förnyade protesterna och rörelserna i efterkrigstidens Europa (1996: 409), utan som en betydelsefull protesterande grupp från I8oo-talet och framåt.

\section{Två aspekter av demonstrationer}

Enkelt uttryckt är demonstrationer - ursprungligen massmarschen, sammankomsten med tal som hålls och den tillfälliga ockupationen av platser (Tilly 1978: 177) - uttryck för relationen mellan det civila samhället och staten eftersom de är en variant av kollektiv handling i vilken "en grupp visar styrka och beslutsamhet i närvaro av allmänheten, av statens agenter och möjligen också av sina fiender" (Tilly 1978: I77; jfr Favre 1990: 15). Två mot varandra stående krafter, eller åtminstone aktörer i samma konfiguration, är en grupp människor och statens agenter. Om politik är kampen och konsten att tala på en grupps vägnar är demonstrationer ett specifikt fysiskt-rumsligt moment i denna process. De utgör en påtaglig konfrontation eller ett möte ansikte mot ansikte och övertagande av ett rum, särskilt i fallet med ockupationer men också genom massmarscher till maktens fästningar. 
Demonstrationer rymmer vanligen två centrala aspekter som är viktiga $\mathrm{i}$ vårt sammanhang. I kravet på rätten att tala för en hel kategori av människor är de ett element i den sociala konstruktionen och samtidigt i representationen av en skara medborgare. De är "representationsgrupper" (Champagne 1984: 36, 39, 40; Rodriguez 1990: I7 och passim). Pierre Bourdieu (1985: 217) beskrev dem som utvecklingen av "klassen-i-representation, med å ena sidan kåren av professionella representanter och all den symbolik som är konstitutiv för dess existens och å andra sidan den mest övertygade delen av dess anhängare”. Den arbetarklass som sålunda representeras genom professionella ledare och anhängare är en "mystisk kropp", skild från arbetarklassen "som sådan”. Demonstrationers representativa funktion ser antagligen olika ut i olika politiska system och kulturer. Den beror på den plats som demonstrationer intar i ett större mönster av handling i samförstånd - mer specifikt på den position de har i relation till "bestående sammanslutningar" i repertoaren av kollektiv handling (Tilly I98I: 2I), eller i den "verktygslåda" ur vilken aktörerna kan välja verktyg för konstruktionen av olika handlingssätt (Swidler 1986: 277). Både demonstrationer och sammanslutningar är verktyg i en större samling, och de förras representativa funktion varierar beroende på den plats som sammanslutningarna intar i de allmänna handlingsstrategier som är förhärskande i ett nationellt sammanhang.

En annan aspekt av demonstrationer, som bygger på deras natur som ett möte ansikte mot ansikte, är deras (mer eller mindre) teatrala karaktär. Demonstranterna representerar inte bara en klass eller annan grupp. De iscensätter den också, de är den klass som representeras i handling, de gör utmaningen och dess aktörer synliga. En massmarsch är en symbolisk erövring av en stad eller ett annat socialt rum; demonstranterna förvandlar öppna platser "till en tillfällig scen på vilken de dramatiserar den makt de fortfarande saknar" (Berger 1968: 755; jfr Champagne 1984: 23; Rodriguez 1990: I12, I32). Demonstranterna anammar eller utnyttjar i sina iscensättningar existerande kulturella scheman (Rodriguez I990: 195), till exempel traditionella former av folklig konfrontation, som de kopplade till festen och skådespelet. Iscensättningarna tar sig följaktligen olika uttryck i olika kulturer.

De båda aspekterna - demonstrationen som representationsgrupp och som iscensättning - visar hur problematisk frågan om ordning i 
demonstrationer är (Monjardet 1990; Monet 1990). Föreställningarna om ordning och oordning beror både på de dominerande föreställningarna om den legitima repertoaren för konstruktion och representation av konfrontativa grupper och på existerande former av iscensättning och sociabilitet som dessa yttrar sig i användningen av det offentliga rummet (vilket varierar med den roll som städer, gator, kaféer och så vidare spelar). Skenbart liknande möten kan därför förmedla olika budskap om hotet mot den allmänna ordningen och om skalan på konflikten i fråga. Den potentiella vändningen mot våld och oordning finns kanske alltid där, men dess hotande närhet upplevs inte på samma sätt i olika kulturer. Vad som är utmanande i en kultur kan vara rutinartat i en annan.

\section{Arbetardemonstrationer}

\section{Första maj och institutionaliseringen av arbetardemonstrationer}

Historien om arbetardemonstrationer i det moderna Finland går tillbaka till ı890-talet, då finska arbetare införde den förstamajdag som hade utvecklats I890 i arbetarrörelsens kärnländer. Ursprungligen bestod första maj av en samtidig endagsstrejk och demonstration för åtta timmars arbetsdag. Det var resultatet av ett av Andra internationalen fattat beslut att ge politisk och kulturell enhet åt arbetarklassen i olika länder (Hobsbawm 2002 [I983]: 3I; Perrot I984a: I43-I45). I Frankrike, för att ta ett exempel, var förstamajdagen en blandning av politisk demonstration, allmän helgdag och en strejk som utlöste "en våg av oväntade strejker" och därmed "undgick initiativtagarnas kontroll". Den "Stora Dagen" visade upp "en vision av snabb förändring", väckte fruktan hos borgerligheten och avslöjade hur "jämförelsevis isolerad arbetarklassen var i det franska samhället”. Som andra arbetardemonstrationer tog den sig "folkfestens form" (Perrot 1984a: 157, 162-165; Perrot 1986: 88).

I kontrast till denna varierade konfrontation och uppvisning - som hade sina motsvarigheter i andra stora länder (Hobsbawm 2002 [1983]: 3I-35) - var det i Finland en grupp yrkesarbetare, tryckeriarbetarna i Helsingfors, som tog initiativ till förstamajfirandet och fortsatte med det i flera år i mycket modest form. Den I maj I890 organiserade de "en utflykt som hade karaktären av demonstration" till en ö (!) utanför 
Helsingfors, som ett svar till Andra internationalen. Karakteristiskt för den allmänna försonliga hållningen var inte bara frånvaron av varje som helst motståndare, utan också det faktum att demonstrationen under de följande åren bara hölls den första söndagen i maj (I maj råkade I890 vara en söndag) (Soikkanen I96r: 4I; 1975: 69).

Nationellt fick förstamajfirandet upp farten I898, pådrivet av den så kallade nykterhetsstrejken. Strejken hade som mål både rusdrycksförbud och allmän rösträtt och spelade en roll i grundandet av det nationella arbetarpartiet året därpå. Massmöten och massmarscher samlade mellan 8 ooo och 15000 människor i de största städerna, och därmed fick demonstrationerna ny synlighet som massfenomen (Soikkanen 1975: 68; Sulkunen 1986: 222, 225, 230, 235). När förstamajfirandet blev nationellt betydelsefullt konfronterade det med andra ord inte alls arbetarna med andra sociala grupper. Det förenade dem snarare med andra strävanden att öka den politiska och kulturella friheten. I linje med denna orientering spelade marscher till maktens högkvarter eller säten uppenbarligen en mer modest och mindre regelmässig roll än till exempel i Frankrike. Där gick demonstrationerna i städerna av vana till "stadshus, prefekturer eller underprefekturer" (Stenius 1977: 157; Perrot 1984a: 157).

Sedan följde en period, mellan I899 och 1905, som har kallats den första demonstrationsperioden i Finland. Den kulminerade 1905 och fortsatte, med sjunkande intensitet, till 1907-1908. Som mest samlades upp till 20 000-30 o00 deltagare (Suppola 1973: 5-6; Carrez 20I0: 53, 56-59; Tikka 2009: 66, I09). Demonstrationerna och andra uttryck för motstånd började bli flera sedan den ryske tsaren från och med I899 tog initiativ till en integrering av det finska storfurstendömet i det ryska förvaltningssystemet. Särskilt 1902 och i början av I905 stod folkmassor och statens agenter mot varandra i demonstrationer i Helsingfors och några andra städer. Betecknande för den representativa aspekten av dessa demonstrationer var att den avgörande skiljelinjen mellan demonstranter och trupper var nationell och inte social. De förra var finländare (och inte bara från folkliga grupper) och de senare huvudsakligen ryssar (eller andra icke-finländare i imperiet) (Jussila 1979: 42-46, 58-6I, 63-64). Deltagarna kunde i en och samma demonstration sjunga både den framtida (från I9ı) nationalsången "Maamme" ("Vårt land") och 
"Arbetarmarsch" (Tikka 2009: 6I-69). Denna period konsoliderade därför inte demonstrationen som en öppen och direkt konfrontation mellan samhällsklasser i Finland, eller åtminstone försvårade eller fördröjde vikten av en nationell front framväxten av demonstrationer som en form av ren arbetarklassutmaning mot överklassen. Dessutom, och nog så viktigt, förblev dessa måttfulla i den meningen att de aldrig resulterade i dödsfall eller andra allvarligt skadade (se Tikka 2009).

Bilden förändrades inte radikalt ens när demonstrationerna var som störst, 1905-1906, även om arbetarna alltmer separerade sig från de andra och lade sig till med röda flaggor, fanor, marschorkestrar samt fasta marschvägar och samlingsplatser (Carrez 20IO: 6I-65). Den mest spektakulära fasen under den perioden utlöstes när det ryska enväldet tillfälligt förlamades av nederlaget i kriget mot Japan. En generalstrejk bröt ut i Finland. Den började som en enorm nationell demonstration förenad med talrika lokala möten mot enväldet, där borgerliga grupper och socialister handlade gemensamt (Jussila I979: 74-75). I demonstrationerna spelade arbetarpartiet, Socialdemokraterna (den beteckningen hade antagits 1903), den viktigaste rollen, men viktigast var att de båda målen, återtagande av de ryska integrationsåtgärderna och ersättande av den antikverade fyrståndsrepresentationen med en enkammarriksdag baserad på allmän rösträtt, i stor utsträckning delades av arbetarrörelsen och de borgerliga grupperna. Båda målen uppnåddes, 1905 respektive 1906 .

Allt detta innebar att den storskaliga mobiliseringen inte ens under sin mest aktiva fas ledde till konfrontationer mellan representanter för olika samhällsklasser, trots oenighet om i vilken ordning som de viktigaste reformerna skulle genomföras. Legitimiteten hos många demonstrationer förstärktes av det faktum att de kunde anses representera inte bara arbetarna, utan finländarna och deras strävanden mer generellt. En annan sak var det jämförelsevis disciplinerade förlopp som massans agerande tog. Som en forskare uttryckte det: de socialdemokratiska ledarna valde "organiserade påtryckningar" i stället för "anarkistiska stämplingar" och ville förmedla en bild av ett starkt men fredligt folk (Carrez 20I0: 65).

I det första allmänna valet 1907 vann Socialdemokraterna 80 av de totalt 200 riksdagsplatserna och blev det överlägset största partiet. Deras väldiga tillväxt skedde på ett anmärkningsvärt organiserat sätt. Det eta- 
blerades en rörelse som effektivt eliminerade alla utomparlamentariska sätt att utöva politiska påtryckningar och strax institutionaliserade massmarschen som en disciplinerad aktivitet ända ned på lokalföreningarnas nivå. "Det har förblivit en bestående och djupt rotad strävan att eliminera spontant motstånd antingen det är kollektivt eller individuellt. Enbart organiserat motstånd (och organiserad makt) har framstått som en legitim aktivitet för [den finska] arbetarrörelsen" (Parikka 1987: 133; se även Carrez 20IO).

\section{Demonstrationer, sammanslutningar och valpolitikens expansion}

I de flesta västländer vann arbetarna i slutet av I8oo-talet och början av 1900-talet gradvis politiska rättigheter genom hårda och ofta utdragna strider i vilka de långsamt lärde sig organisera, mobilisera och handla kollektivt mot statens maskineri, först i strejker och sedan, efter att ha vunnit vissa rättigheter, i val med egna partier. Denna process tog i regel flera decennier. Ur denna process utvecklades demonstrationen som en särskild form av kollektiv handling, liksom också sammanslutningar med specifikt syfte, programförklaringar, styrkedemonstrationer och olika vädjanden om folkligt stöd (Tilly 1978: I13; 198I: 22).

Men i Finland håller inte den bilden av en långsam och utdragen strid i vilken de folkliga grupperna lärde sig denna repertoar. Det snabba och fullständiga genombrottet för valpolitiken skedde 1906 innan demonstrationer hade etablerats som ett element i en långsiktig direkt konfrontation med statsmaskineriet. Det var som om traditionen inte hade tid att verkligen utvecklas. Därtill kom att valpolitikens expansionstakt inte bara var spektakulär, utan skedde på ett ytterst organiserat sätt med en (förvisso tillfällig) ökning av antalet betalande medlemmar i det socialdemokratiska partiet från 16 ooo i början av 1905 till I09 ooo i oktober I906 och med en ökning av antalet Folkets Hus från 47 år 1905 till 940 år 19I6. Denna utveckling skilde sig radikalt från vad den ryska krisen I905 framkallade i de baltiska provinserna. Där utlöste den bondeuppror i vilka adelsmän dödades, gods brändes ned, arkiv förstördes och kyrkor plundrades.

En avgörande faktor bakom demonstrationernas fredliga karaktär i Finland var den allt större aktivitet som sammanslutningarna visade upp 
under I80o-talets senare hälft. Finland var i det avseendet inget undantag bland de nordiska länderna, men ingen annan stans fick sammanslutningarna en så framträdande roll i formandet av massans handlande under en spektakulär mobiliseringsvåg. Villigheten att följa den organiserade aktivitetens grundsatser bidrog både till ett ordnat uppträdande i demonstrationer och fick människor att gå in i det socialdemokratiska partiet (se Carrez 2010).

Till detta kommer att de former av förindustriell folklig kultur och kollektiv handling som kunde ha tjänat som potentiellt förråd för olika sätt att iscensätta demonstrationer på var svagt utvecklade i Finland. Enligt Charles Tilly (198r: 20) fanns det två återkommande dramatiska former av kollektiv handling i I700-talets Västeuropa. Den första formen utgjordes av "hungerkravaller, samlat motstånd mot rekrytering till militärtjänst, organiserade invasioner av åkrar och skogar och uppror mot skatteindrivare". De flesta av dessa former av kollektiv handling, inklusive hungerkravaller, utnyttjades föga i Finland, med få lokala undantag. Mycket längre än i andra västeuropeiska länder kunde finländarna minska utrymmet för öppen konflikt med staten eller med de stora jordägarna, till exempel genom att dra sig undan till obebodda trakter.

Samma sak gäller för den andra formen, de iscensättningar som var mindre öppet konfrontativa och mindre synliga "men i vissa avseenden mer inflytelserika", nämligen etablerade ritualer och offentliga fester under vilka vanliga människor uttryckte klagomål eller krav (Tilly I98I: 20). Detta är förvisso inte särskilt överraskande med tanke på de långa vintrarna och den glesa befolkningen. Sociabiliteten var långt mindre utvecklad på den finska landsbygden än på den centraleuropeiska. Och vad gäller den urbana variationen var den också mindre rik i Finland än i sydligare delar av Europa. "De institutioner som skapade en anda av kamratskap och samhörighet i västeuropeiska städer - skrån och gillen, kaffehus, fester, karnevaler - lyste med sin frånvaro i Finland" (Kirby 1988: 69).

Den relativa stramheten hos de första arbetardemonstrationerna står i skarp kontrast till fester och uppvisningar i den franska traditionen. Där, i demonstrationerna på landsbygden, "gav politiken möjlighet till och utgjorde mål för expressiva aktiviteter, och folkloren var ett medium för 
det", som Maurice Agulhon (I979: 266) beskriver vikten av rural sociabilitet i sin bok om politik och kultur i franska södern under i8oo-talets första hälft. För de första strejkande (i städerna) var demonstration detsamma som fest, berättar Michelle Perrot. Strejkerna var "proletärens stora helgdagar". De innebar framför allt ett fullständigt brott med fabrikens vardagliga rutiner. "Många gatudemonstrationer är inget annat än glada processioner, i takt med en blåsorkester, en möjlighet att sjunga, att liva upp sig, att njuta av den friska luften. [...] Första maj I89o, den första arbetarfesten och [...] den första generalstrejken, bringade denna atmosfär av folklig glädje till klimax" (Perrot 1984b: 160).

En annan dimension av iscensättandet, erövringen av gatan, är återigen ett element som var mycket mindre utvecklat i Finland än i Frankrike, med möjligt undantag för de stora demonstrationerna 1904-1906. De franska arbetarna hade under I8oo-talet "bestämda uppfattningar om det urbana rummet: rätten att korsa staden fritt, att använda allmänningarna [den gamla bondetermen används medvetet här] [...] att vara i stadens hjärta”. Dessa strävanden var väl grundade i de vardagliga livsmiljöerna - butiker, krogar, danslokaler, obebyggda tomter. Arbetarna "krävde sin rätt till staden och till gatan" (Perrot I986: 87, 88, I06).

Elementen av iscensättning i festen och konfrontation förblev alltså underutvecklade i de första finska (arbetar)demonstrationerna. De var mer enhetliga, mer disciplinerade, mindre spektakulära och av allt att döma mindre konfrontativa än i stora delar av Västeuropa.

\section{Politiska kriser}

Denna bild förändrades genom den oerhörda betydelse som två andra politiska kriser fick för föreställningen om demonstrationer i Finland: först krisen 19I7, strax före inbördeskriget, och sedan krisen under åren efter andra världskriget. Under dessa avgörande perioder förvandlades massmarscher och offentliga möten ibland till konfrontationer med statens agenter. Till föreställningen och idealet om disciplin och ordning $\mathrm{i}$ demonstrationer lades en stark känslighet för oordning.

I9I7 blev demonstrationerna i städerna intensivare än vad de hade varit tidigare och någonsin skulle komma att bli, beroende på frånvaron av en inhemsk armé och till och med av en reguljär poliskår i Finland. 
Efter februarirevolutionen i Ryssland försvann statens auktoritet i imperiet, inklusive Finland, och förstärkte den oro som demonstrationerna ändå skulle ha väckt. Senare uppfattades massmötena och massmarscherna dessutom som förspel till inbördeskriget, som bröt ut i januari I9I8, nästan omedelbart efter den finska självständighetsförklaringen i december 1917. I den borgerliga föreställningsvärlden kristalliserades demonstrationerna I9I7 som ett plötsligt frisläppande av mörka krafter. Det ryska ordet svoboda, "frihet", blev en symbol för kaos och kopplade samman de finska "huliganerna" med de odisciplinerade ryska soldater som var stationerade i landet 1917. I många dystra retrospektiva tolkningar ansågs dessa demonstrationer representera den finska arbetarklassen som vilseledd av sina ledare och eggad av bolsjevikerna vände sig mot sitt eget fosterland.

Från och med 1944 tilläts kommunister och vänstersocialister, enligt bestämmelserna i vapenstilleståndet med Sovjetunionen, träda in på den politiska scenen efter en femton år lång period av faktisk repression. De intog en viktig roll i den finska arbetarrörelsen och genomförde ett stort antal demonstrationer som ifrågasatte landets politiska orientering och gav stöd åt strejker. 1949 kulminerade demonstrationerna i en sammanstötning där två människor dödades av polisen. Detta är unikt i den finska demonstrationshistorien.

Viktigt för konsolideringen av demonstrationer som något att frukta eller avsky är självklart det faktum att de båda konfrontationerna I9I7 och I945-1949 var kopplade till en kris med Ryssland (eller Sovjetunionen). Under båda perioderna tycktes ett inre hot mot rådande maktförhållanden smälta samman med ett yttre hot, vilket bland borgerliga grupper kraftigt bidrog till rädslan för kaos. De kaotiska elementen i den inre utmaningen från arbetarklassen ansågs vara inspirerade av en yttre, rysk smitta.

Det är alltså inte överraskande att dessa perioder framkallade skräck hos borgerliga grupper. Men det är betecknande att spontaniteten och "aktionismen" i stort sett förkastades även inom arbetarrörelsen. 1917 tog Socialdemokraterna själva avstånd från spontana demonstrationer, och faktiskt var rädslan för oordning ett av huvudmotiven för grundandet av specifika arbetarmiliser det året (Salkola 1985: 207-208, 229-232, 238). 
Efter andra världskriget ansträngde sig till och med kommunistpartiets ledning för att hålla tillbaka de mer konfrontativa formerna av kollektiv handling (Parikka I988a: IO-II, I988b: 24-27).

Händelserna 1917 och I9I8 påverkade uppenbarligen bilden av demonstrationer även i en annan mening. Det enda ögonblick som möjligen kunde ha lett till en något rikare repertoar av demonstrationer och till en tydligt positiv inställning till dem missade man kanske just då. Som redan påpekats började generalstrejken 1905 och åtföljande förvandling av det politiska systemet som en enorm nationell demonstration mot ryssarna, där borgerliga grupper och socialister agerade tillsammans. Även om de snart gick i politiskt olika riktningar återstår det faktum att denna våg av kollektiv handling var en högst kraftfull katalysator i nationaliseringen av det politiska livet, en i stort sett delad upplevelse av nationell frigörelse. Den hade goda möjligheter att bli den akt genom vilken modern kollektiv handling grundades i Finland, "ett lager av ritualer, symbolik och moraliska maningar" (för att parafrasera Hobsbawm 1983: 6), med demonstrationen som ett viktigt element i den matris eller verktygslåda för handling som var på väg att utvecklas. Men den förfärliga chocken efter inbördeskriget i förening med ryska revolutionen skulle kraftigt påverka bilden av den bara ett decennium senare. Skuggan av den misslyckade revolutionen skulle falla mörk över generalstrejken 1905 och få den att framstå som ett förspel till inbördeskriget och konsoliderade en skarp åtskillnad mellan ordning och oordning.

\section{Bondemarschen 1930}

Det sades ovan att de viktiga återkommande former av kollektiv handling som var kända från I70o-talets västeuropeiska landsbygd praktiskt taget var obekanta eller dåligt utvecklade i Finland. Den begränsade sociabiliteten på finska landsbygden ledde inte till iscensättningar efter mönster av hungerkravaller eller offentliga fester och ritualer. Ändå tycks i ett fall just denna sociabilitet ha fungerat som kulturell ram för en stor demonstration. Denna bekräftar på ett paradoxalt sätt och fördjupar kanske bilden av den finska demonstrationen som en organiserad och disciplinerad händelse. 
I juli 1930, när den finska varianten av fascism nådde sin höjdpunkt, visade den prov på stor beslutsamhet i Helsingfors. Omkring tolvtusen människor, främst bönder, marscherade mot huvudstaden och krävde utplåning av varje som helst form av "marxism" i Finland. Vid huvuddemonstrationen var de mest centrala politiska gestalterna i landet närvarande. Bondemarschen, som den kallades, var en disciplinerad manifestation av den starke finske bondens religiösa och patriotiska dygder som kontrast till det förmenta styre av dekadans och gudsförnekelse som störtade landet i samma oordning som hade rått I9I7. Marschen blev en spektakulär symbolisk demonstration mot det "röda kaosets" krafter och med rötterna i bondesamhällets traditionella värden. Den påminde om de vitas segerparad i Helsingfors efter inbördeskriget (se Siltala 1985: I20-I23). I finländarnas kollektiva minne kom denna marsch att få en mer central roll än någon annan massmarsch under förra århundradet.

Förutom den performativa aspekten, iscensättandet, var också den representativa avgörande. Händelsen var i själva verket ett element i konstruktionen och därmed representationen av den "verklige" finske bonden, en dimension som bidrog till att ge legitimitet åt marschen i mellankrigstidens borgerliga kultur.

\section{Studentdemonstrationer under I8oo-talet och början av 1900-talet}

Förutom arbetarna har särskilt universitetsstudenterna haft en egen demonstrationshistoria i Finland. Traditionen sträcker sig från I8oo-talets början fram till perioden efter andra världskriget och längre, och tycks, med ett betydande undantag, bekräfta bilden ovan av den finska demonstrationen. Studentdemonstrationerna har i regel varit disciplinerade och laglydiga; direkta konfrontationer har förekommits eller förhindrats. Slående är det återkommande kravet på självdisciplin från studenterna själva, det vill säga en uppenbarligen grundlig internalisering av restriktionerna. En diversifiering, inklusive tillfälliga småskaliga konflikter med polisen, har bara inträffat under de senaste decennierna, samtidigt som demonstrationerna har börjat förlora sin rena studentkaraktär. 


\section{Självkontroll i förhållande till Ryssland}

Under I800-talet och i början av I900-talet var skälen till självpålagda restriktioner inbyggda i Finlands politiska position. Dess ställning som en separat politisk enhet, ett storfurstendöme i det ryska imperiet, vilade ytterst på en känslig politisk balansgång: de finska byråkratiska ledarna var väl medvetna om att begränsningarna för det ryska inflytandet byggde på vidare ryska överväganden som finländarna inte hade någon kontroll över. Grundproblemen för den finska politiska eliten var två: Vilken var ryssarnas (verkliga) ståndpunkt och hur skulle finländarna definiera sin egen handlingslinje i förhållande till den ryska? Behovet av en varaktig bedömning av ryssarnas ståndpunkt betydde att finländarna ständigt föregrep deras tänkbara reaktioner i kritiska situationer eller, mer exakt, föregrep vilka situationer som ryssarna skulle betrakta som kritiska eller oacceptabla i sina relationer med dem. Detta sågs som viktigt i strävan att bevara eller vidga Finlands manöverutrymme.

I fallet med demonstrationer - en rad olika kollektiva handlingar som var oförutsägbara och potentiellt okontrollerbara på grund av sin natur som möte ansikte mot ansikte - betydde den ståndpunkten att den finska eliten, för det första, hade som mål att i förväg minimera alla fall av kollektiv handling som kunde uppfattas som kritik av ryssarna och, för det andra, försökte göra detta utan publicitet och utan öppen konfrontation med potentiella demonstranter. Den försökte med andra ord genom förhandlingar få dem att avstå från sina planerade aktioner. Situationen resulterade i en frivillig återhållsamhet hos demonstrationerna utifrån en bedömning av den tänkbara eller sannolika reaktionen från ryssarnas sida. Därmed utvecklades tvunget ett starkt element av självpåtvingad kontroll som omfattade inte bara den ledande gruppen utan även demonstranterna, som i stor utsträckning kom att internalisera riskerna med sina planerade uppvisningar. Det är karakteristiskt att J.V. Snellman, den finska nationalismens store ideolog, I86I, vid en av de mest uppseendeväckande demonstrationerna under i80o-talet uttalade en kraftfull, förringande dom över "passivt motstånd" och "fredliga demonstrationer", som han betraktade som helt olämpliga för de finska förhållandena: "Den så kallade fredliga demonstrationen [...] syftar till att göra den nuvarande situationen helt omöjlig utan att skaffa 
sig kontroll över framtiden." Den verkade inte vara till någon nytta för Snellmans huvudintresse, den nationella överlevnaden (Huxley 1990: 98-I05, citatet på s. 98).

Allt detta gällde framför allt det akademiska samhället, både som helhet i dess relationer till landets politisk-byråkratiska ledning och mer specifikt studenterna i deras förhållande till professorerna och universitetsledningen. Den akademiska aspekten i uppvisningen av styrka och beslutsamhet framträdde därför att borgerligheten var svag och städerna föga utvecklade i I80o-talets Finland. Universitetet i Helsingfors utgjorde fram till mitten av i8oo-talet och längre än så praktiskt taget det enda forumet för offentlig diskussion i hela landet, och därför riktades den politiska kontrollen mot det och speciellt mot studenterna (Klinge m.fl. 1989; Klinge 1967a, 1967b). Problemen som de tsaristiska myndigheterna hade med de ryska universiteten gjorde dem säkert också känsliga för varje som helst uttryck för liberal eller separatistisk opposition från den finska utbildade klassen. Och slutligen var tronarvingen kansler för Kejserliga Alexanders-universitetet, vilket otvivelaktigt gjorde eventuell oro bland studenterna synlig för det ryska enväldet.

Följaktligen är det kanske inte att undra på att historien om de finska studentdemonstrationerna från I8Io-talet och framåt är en rad skenbart mindre och oskyldiga incidenter som dock var starkt laddade och vars betydelse tycks gå långt utöver de faktiska händelserna. Demonstrationerna växte under århundradets gång tillsammans med vårfester, som för det mesta förblev en fredlig (och ibland avgjort lojalistisk) form av studentsamvaro. Varje gest eller oförsiktigt uttryck eller mer eller mindre opolitiskt bråk rapporterades till tsaren och fick lätt starka politiska övertoner. Incidenter som i ett europeiskt perspektiv var blygsamma kunde få allvarliga konsekvenser, såsom upplösningen av studenternas egen organisation på I850-talet. Den självdisciplin som universitetsledningen föreläste om anammades i de flesta fall av studenterna. De var vanligen medvetna om att "bruket av demonstrationer var ett spel med höga insatser", som det uttrycktes av Matti Klinge som har studerat studenternas organiseringsprocess (Klinge 1967a: I8-19, I52-159, 206-209, 213 [citat]; I967b: I29-133, 23I-240; 1968a: 208, 2I4-250, 262-282).

Demonstrationernas begränsade skala och sena utveckling syns tydligt i studenternas reaktion på den revolutionära aktiviteten I848 ute i 
Europa och på de tsaristiska myndigheternas fördröjda sammankallande av den finska ståndsförsamlingen I86I. I det förra fallet kom reaktionen - som har betraktats som den första politiska massdemonstrationen i Finland - först året därpå och då huvudsakligen i form av ett uppbåd på hundrafemtio studenter som förde oljud mot en professor vars utnämning hade blivit en symbol för universitetspolitikens konservativa inriktning. Allt som allt var studentdemonstrationerna "väldigt modesta". Ekot från demonstrationerna gick omedelbart till Sankt Petersburg och fick universitetsstyret att skärpa kontrollen över studenterna (Klinge 1967a: I68-I7I; Stenius 1980: 200 [citat]).

Det senare fallet framkallade ingen konfrontation eftersom det inte betraktades som en utmaning (även om det var något suspekt i förhållande till ryssarna), utan som ett uttryck för sympati med den finska politiskadministrativa eliten, och eliten hade inte kommit i någon verklig konflikt med det ryska enväldet. Demonstrationen I86I var ändå betydelsefull som "århundradets enda 'parisiska' demonstration" i Finland. Det var en händelse som otvivelaktigt påverkade deltagarna själva. Det nya var, för det första, att denna massmarsch samlade människor från olika samhällsklasser (inte bara studenter utan särskilt också hantverkare) och till och med mer än tusen personer och, för det andra, att demonstranterna uttryckte sig till förmån för konstitutionella principer (Klinge 1967a: 19, 1967b: 13II34; Stenius I980: 200 [citat]).

\section{Konfrontationer under mellankrigstiden}

Det är i överensstämmelse med den tidigare utvecklingen att studentdemonstrationerna blev mer konfrontativa samtidigt som Finland bröt sig loss från Ryssland. I 1920- och 1930-talens Finland visade den utbildade klassen en aldrig förut skådad fientlighet mot Ryssland (som förvandlats till en sovjetstat), och studentdemonstrationerna som helhet blev mer våldsamma och aggressiva än någonsin tidigare. Detta gällde inte bara i relation till Ryssland utan också i relation till de inhemska makthavarna, vilket harmonierar väl med den tidigare dubbla återhållsamheten: självkontroll gentemot ryssarna hade inneburit självkontroll gentemot de inhemska (universitets)myndigheterna.

Den tidens dominerande studentorganisation, Akademiska KarelenSällskapet (AKS), drev kampanj mot den svensktalande och tvåspråkiga 
överklassen (inklusive delar av universitetseliten) och mot Sovjetunionen (inklusive attacker mot monument och andra symboler från den "ryska perioden”). Förutom militärt organiserade massmarscher till monumentet över nationalhjälten J.V. Snellman och demonstrationer framför den sovjetiska legationen omfattade AKS repertoar bränning av flaggan och av dockor och bojkott av föreläsningar eller störningar av dem. Nationalistiska studenter agerade till och med i strider mellan finsktalande och svensktalande gymnasieelever (Klinge I968b: 99-I03, I26-I83).

Hypotesen om det ryska sambandets betydelse för den självpålagda disciplinen tycks få stöd av studentdemonstrationerna i slutet av 1940talet. Då blev mindre incidenter åter starkt laddade på grund av sina förment eller reella antisovjetiska övertoner och ledde snabbt till skärpning av både den yttre kontrollen och studenternas självkontroll (Klinge I968b: 232-234, 25I).

\section{Studentdemonstrationer på 1960-talet}

Den mest intensiva perioden för studentdemonstrationer efter andra världskriget var på 1960-talet. De var paralleller till dem som organiserades av stora studentrörelser på annat håll, men var samtidigt ett distinkt finskt fenomen.

I964 organiserade De Hundras Kommitté, en studentdominerad fredsorganisation som huvudsakligen hämtade inspiration hos den samtida engelska fredsrörelsen, sin första demonstration. Från denna blygsamma början blev demonstrationer i Helsingfors och andra städer gradvis ett återkommande fenomen under åren som kom. De kulminerade 1968. Från början av 1970-talet började de förlora sin oppositionella betydelse. Efter demonstrationerna mot den iranske shahens besök i Finland I970 smälte de delvis samman med arbetarrörelsens institutionaliserade demonstrationer och upphörde i stort sett (von Bonsdorff I986: 87-97, 176-212, 302-309; Suppola 1973: 22-29, 36-39).

Av de hundraåttiofyra demonstrationer som enligt en studie ägde rum under perioden 1964-1970 hade den överväldigande majoriteten formen av en massmarsch eller en sammankomst där tal hölls eller en kombination av dem. I de flesta fallen uttryckte demonstranterna åsikter 
i internationella eller besläktade frågor; framför allt demonstrerade de mot USA:s krigföring i Vietnam och uttryckte sin solidaritet med folken i tredje världen. Perioden kulminerade 1968, då den sovjetiska ockupationen av Tjeckoslovakien lades till frågorna. Ämnena och prägeln på de viktigaste organiserande aktörerna visar tydligt vilken central roll som studenterna spelade och hur nära de stod sina kamrater i andra länder (Suppola 1973: 22-36).

Demonstrationerna följde delvis utländska mönster; de visade upp former som var nya i Finland, till exempel ropande av slagord, sittning på gator och springande i takt (Hentilä 1970: 28). Det fanns tendenser till överskridning av den legaliserade kollektiva handlingens gränser på ett sätt som påminde om de samtida demonstrationerna i Frankrike eller andra länder, till exempel bränning av militära inskrivningsböcker (von Bonsdorff 1986: 207-208; Lahtela 1967: 87).

Resultatet blev ändå omisskännligt finskt med tonvikt på ordning och disciplin och undvikande av öppen konfrontation. Karakteristiskt för den begränsade roll som gatudemonstrationer spelade för fredsaktivisterna är det faktum att den grupp som betonade deras vikt som det primära sättet att utöva påtryckningar svårligen lät sig skiljas från den dominerande aktivistgruppen. Majoriteten föredrog forskning och rationell argumentation och betraktade demonstrationer utifrån perspektivet att de skulle ge (rationell) information om frågor som de dominerande massmedierna försummade: demonstrationer "är ett rationellt sätt att påverka beslutsfattarna i samhället" (von Bonsdorff I986: 98-99; Mäkelä I967: 89 [citat]). Demonstranterna skulle lära sig och praktisera "direkta icke-våldsaktioner", vilket krävde självdisciplin; icke-våld skulle göras till den överordnade principen och individers okränkbarhet skulle respekteras. Det är inte att undra på att legaliteten, eller åtminstone medvetet undvikande av konfrontationer med polisen, betonades. Friheten att demonstrera sågs som en konstitutionell rättighet som måste aktiveras, "ett demokratiskt sätt att utöva inflytande", och måste utnyttjas på ett organiserat sätt. Man gjorde också upp en demonstrationsguide, på initiativ av inrikesdepartementet (Suomela 1968: I40; von Bonsdorff I986: 207; Björklund 1968: I42; Pirinen 1968: 134; Taipale 1970: 7; Mäkelä I967: 89; Hannula 1968: I35 [citat]). 
ARKIV $\mid$ NR 8

Vikten av denna inställning går utöver de enskilda aktivisterna; många "demonstrationsspecialister" förblev huvudgestalter under hela perioden, fram till början av 1970-talet. En av dem skrev I970:

Generellt har demonstrationerna i Finland varit offentligt organiserade och haft en icke-våldskaraktär; [demonstranterna] har varit beredda att förhandla med polisen och har samtidigt genom olika kanaler försökt informera allmänheten om demonstrationernas mål. De har varit kopplade till större kampanjer, till medvetandehöjning (Taipale I970: 22-23).

Denna uppfattning bekräftas av den ovan åberopade studien om perioden 1964-1970. Den drog slutsatsen att det under i960-talet "hade förekommit relativt få våldsamma demonstrationer i vårt land". Motstånd mot polisen förblev ett sällsynt fenomen. Faktiskt förekom det en gång under dessa år en våldsam konfrontation. 1970, då kulmen redan var passerad, ledde demonstrationerna mot shahen till öppna konfrontationer mellan polis och demonstranter (Suppola 1973: 44, 55 [citat, kursiv utelämnad]; von Bonsdorff I986: 307-308). ${ }^{2}$

Den finska avskyn för öppen konfrontation demonstreras åskådligt genom besöket av Karl Dietrich Wolff, en av de främsta ledarna för den tyska studentrörelsen, i Helsingfors sommaren 1968. När han bröt genom poliskedjan framför den västtyska handelslegationen för att erövra Förbundsrepublikens flagga följde ingen efter honom. Wolff var "rasande", han kunde inte förstå de finska studenternas "försiktighet" (von Bonsdorff I986: I92, 2II-2I2).

En annan kontrast erbjuder maj 1968 i Paris. Där accepterade man inte bara konfrontation med polisen, utan sökte det aktivt efter en viss punkt. Det handlade om en process av aktion och reaktion i växande skala, en eskalering av konfrontationerna från de tidiga ockupationerna i Nanterre och Sorbonne och polisens utdrivning av studenterna från Sorbonne fram till gatustriderna mellan studenter och polis under natten till 13 maj. För de finska aktivisterna låg den omedelbara lärdomen av maj 1968 i det politiska bakslaget, det vill säga resultatet av de följande valen i Frankrike. För dem visade högerns seger att de franska studen-

2. Se också samlingen av artiklar om demonstrationerna mot shahen: Mielenosoitukset ja poliisi 22.-26.6.1970 (1970). 
terna hade gjort fel när de valde direkt - och våldsam - konfrontation med myndigheterna och underlät att ge "någon verklig information" till allmänheten (Hamon \& Rotman 1987: 427-489; "Ranskan opetukset" I968: 107 [citat]).

Även festen och skådespelet utgjorde uppenbarligen en mer central aspekt i Frankrike än i Finland. I Frankrike var aktionen - liksom rörelsen i sin helhet - en kombination av "strejken och festen, de dansade mötena, de vältaliga väggarna, begärets ordning" (Hamon \& Rotman 1987: 529). "Kämpa och roa sig" bildade myntets två sidor för Daniel Cohn-Bendit (Hamon \& Rotman 1987: 432), som själv förkroppsligade de ständigt pågående försöken att överskrida vardagslivets gränser, att försvara festen. Känslan av skådespel förstärktes uppenbarligen under eskaleringsprocessen. Många var högst medvetna om att de uppträdde på en (nationell) scen, en situation som på en nivå uttrycktes i ockupationen av Théâtre de l'Odéon (Hamon \& Rotman 1987: 432): "En scen, de behöver en scen!"

Men trots det allmänna ordnade och disciplinerade uppträdandet, som var väl i linje med den finska traditionen, såg varken organisatörerna eller allmänheten demonstrationerna som något bekant. För organisatörerna var de en ny form av kollektiv handling, ett potentiellt effektivt sätt att kommunicera som skulle bevara sin oförutsägbarhet och inte stelna i en ritual, vilket hade hänt med de traditionella (arbetar-) demonstrationerna (Mäkelä 1967: 89; Taipale 1970: 7). Det mest påtagliga i allmänhetens inställning var en tydlig fientlighet. Det var påtagligt i olika reaktioner från förringande och förolämpande kommentarer på gatan till åsikterna i pressen. Demonstrationerna ansågs i allmänhet vara en upplösning av ordningen och/eller inspirerade av kommunisterna. Det existerade även en viss fientlighet i de etablerade studentorganisationerna. "Det ligger inte i den finske studentens tradition att gå ut på gatorna", sade ordföranden i Nationella studentunionen 1968 (Mielenosoitukset ja poliisi 1970; von Bonsdorff 1986: 205 [citat]).

Även bland arbetarna var reaktionerna negativa eller i bästa fall likgiltiga. Det härrörde förmodligen ur det faktum att "demonstrationstraditionen i den finska arbetarrörelsen är mycket seriös till sin anda”, som en kommentator uttryckte det (Hentilä I970: 28). 
Det är inte så långsökt att påstå att det i dessa reaktioner yttrade sig den ovan skisserade spänningen mellan ordning och oordning. I den finska traditionen värdesattes inte bara bevarandet av ordningen som sådant, utan det accentuerades med kraft genom känslighet för oordning och kaos. Det var under dessa förhållanden som studenternas nya repertoar, även om den inte skilde sig så mycket från traditionen och även om den förblev föga konfrontativ med internationella mått mätt, framkallade motvilja och irritation bland olika samhällsgrupper.

En intressant aspekt är den självmedvetna betoningen av demonstrationer som ett sätt att kommunicera, som ett sätt att ge information. I förmedlingen av budskapet lade man ned stor omsorg på att inte irritera eller såra allmänheten. Men trots dessa ansträngningar blev bara små nyheter i gester och uppträdande starkt laddade, och deras betydelse växte lätt i överväldigande proportioner. Enligt åsikten hos en framstående aktivist var det ett allvarligt misstag att "ställa till med en scen"; det gav ammunition åt motståndarna till demonstrationer (Taipale 1970: I4). Mindre konfrontationer i fysisk-rumslig mening blev förbundna med större konfrontationer i symbolisk mening.

Relationen mellan de båda aspekterna är klart urskiljbar i den demonstration med vilken den finska studentrörelsen nådde sin klimax och som under de följande åren fick en nästan mytisk karaktär. Den 25 november 1968, en dag innan hundraårsfirandet av studentförbundet vid Helsingfors universitet skulle äga rum i studenternas eget klubbhus (en imponerande byggnad i hjärtat av Helsingfors), ockuperade studenterna huset. Det officiella firandet med ett stort antal gäster, inklusive republikens president, måste flyttas till annan plats (von Bonsdorff I986: 9-4I).

$\AA$ ena sidan framstår den konfrontativa aspekten av detta övertagande av en plats som jämförelsevis begränsad. Det är viktigt att påpeka att den finska rörelsen kulminerade i ockupationen av studenternas eget hus. I demonstrationen ställdes inte studenterna direkt mot en motståndare. De förblev inom ett fysiskt isolerat rum ägt av det egna förbundet, bland sig själva. I Frankrike, för att ta ett annat fall, konfronterades studenterna både genom ockupationen av universitetsledningens sammanträdesrum i Nanterre (ett viktigt steg i eskaleringen av 68-rörelsen) och 
genom ockupationen av Sorbonneuniversitetet med universitetsmyndigheterna och i det senare fallet med statens agenter. Den första ockupationen av Sorbonne slogs ned av polisen (Hamon \& Rotman 1987: 427-429, 450-456).

I Finland var kulminationspunkten förbunden med frånvaro av en tydlig motståndare inte bara fysiskt utan även symboliskt. I ockupationshandlingen ingick ingen öppen utmaning mot myndigheterna eller andra grupper i samhället. Ockupationen var förvisso en protest, men dess mål var bara vagt definierat. Det handlade om den "byråkratiserade" eller "elitistiska" ledningen för den egna organisationen och "etablissemanget" mer generellt. Det är karakteristiskt för protesten att ockupanterna skickade en hälsning till "kamrat presidenten", som ju som gäst vid hundraårsfirandet kunde känna sig sårad jämte de andra firarna (von Bonsdorff I986: IO-20, 28 [citat]).

Det är intressant att notera att höjdpunkten för den finska studentaktivismen var så pass inåtriktad att den bara med svårighet kunde betraktas som en demonstration om man godtar Charles Tillys villkor om närvaron av en allmänhet, av statens agenter och möjligen också av fiender (1978: 177). I ockupationen av studenthuset i Helsingfors var praktiskt taget ingen allmänhet och inga statliga agenter närvarande - i ordets konkreta, fysiska mening.

Men å andra sidan fick händelsen ett oerhört eko i pressen, tv och allmänna opinionen generellt som utmaning mot den accepterade ordningen och fungerade som katalysator i kristalliseringen av den ideologiska konfrontationen mellan studentrörelsen och högern och socialdemokratin. Även om ockupationen i snäv fysisk mening knappast var en konfrontation var den med andra ord starkt symboliskt laddad.

\section{Nutida demonstrationer och traditionen}

De två grupper som framför allt har representerats i de finska demonstrationerna är arbetarna och universitetsstudenterna. Det är ingen tillfällighet. 1900-talet var arbetarklassens tid i Finland som på annat håll, och studentdemonstrationerna kristalliserade den utbildade klassens betydelse i den finska nationsbildningen från i80o-talet fram till 1960- 
och I970-talen, eller till perioden då inbördeskrigets trauma slutligen diskuterades och arbetades igenom.

Som iscensättningar har demonstrationerna vanligen varit anmärkningsvärt modesta och ordnade och speglar därmed sammanslutningstraditionens styrka i konstruktionen av kollektiva handlingslinjer. Även om detta sammanhang otvivelaktigt bidrar till att förklara dominansen av ordning i den finska traditionen förklarar det inte ensamt varför det existerar, eller åtminstone existerade, en väldigt stark spänning mellan ordning och oordning. För att förstå detta egendomliga förhållande måste man frammana avgörande perioder i relationen till Ryssland eller Sovjetunionen; de har utlöst massaktioner som har väckt fruktan eller till och med fasa bland icke-kommunistiska grupper. Uppenbarligen går demonstrationernas legitimitet som representation och deras ordnade förlopp hand $\mathrm{i}$ hand $\mathrm{i}$ den meningen att det senare är en förutsättning för det förra. För att vara legitima måste demonstrationerna genomföras på ett disciplinerat sätt.

Hur har demonstrationerna utvecklats de senaste decennierna, både som iscensättning och som representation? Hur stor tyngd har traditionen i dag? Demonstrationerna har, kort sagt, konsoliderat sin roll som en reguljär form av kollektiv handling, iscensättningarna har blivit mer mångskiftande, och representationen av bestämda sociala grupper har förlorat mycket av sin skenbara självklarhet. Massmöten och massmarscher kopplas till husockupationer, blockader, (gatu)fester och så vidare, företeelser som i stor utsträckning har hämtats från den rika europeiska eller västerländska repertoaren. Demonstrationerna delar också många teman med uppvisningar på annat håll. Inhemska frågor om brödfödan ackompanjeras av eller smälter ibland samman med frågor med en global dimension, som invandring, kärnkraft eller klimatförändring. Grupperna för vilka demonstranterna förutsätts tala är mer vaga och mångfaldiga än förr. Förstamajtåget har praktiskt taget försvunnit i sin traditionella form, och studenterna framstår som bara en bland många protesterande grupper. Finska aktivister kan också vara delaktiga i demonstrationer på annat håll i Europa, vilket för in den nivån i den inhemska diskussionen.

Men kontinuitet märks också vad gäller både iscensättning och representation. Demonstrationerna är fortfarande anmärkningsvärt fredliga 
och laglydiga, och varje avvikelse från detta förlopp fördöms allmänt. Detta har varit tydligt i reaktionerna på ett antal militanta protester som konkret ställt aktivister och polis mot varandra. De mest iögonfallande av dessa har varit de så kallade snyltgästdemonstrationerna (på finska kuokkavierasmielenosoitukset) under det här århundradets första år, vilka störde de elitdominerade festligheter som hölls på självständighetsdagen under den finske presidentens värdskap (Lindström 20I2). En nyckelpunkt i den kritik som mötte demonstranterna, och som inte gick att skilja från anklagelsen att de framkallade våldsamma sammanstötningar med polisen, var påståendet att de inte representerade några andra än sig själva.

Det argumentet kommer lätt på tal i Finland och spelar en stor roll i avlegitimeringen och förkastandet av en demonstrations betydelse. Den påstådda icke-representativiteten fortsätter att göra demonstrationens roll i repertoaren av kollektiva handlingar suspekt och i bästa fall begränsad. Den uppfattningen skiljer sig markant från den franska, som den exempelvis kommer till uttryck i en ledare i Le Monde från 30 april 2002: ”Demonstrationen är en form av politiskt engagemang. [...] Att demonstrera är i en demokrati inte mindre legitimt än att delta i val, underteckna en petition eller gå in i ett parti. [...] Det finns ingen anledning att ställa gatan mot valurnan.”

Kontrasten mellan den franska och den finska föreställningen om representation har vidare förgreningar. I den finska politiska kulturen består representation framför allt av delegering, eller att ge någon individ eller något organ mandat att re-presentera en grupp människor (se Alapuro 2006). I Frankrike framstår representationen däremot som mindre självklar, som mer öppen eller flexibel; den är något som hela tiden konstrueras (jfr Alapuro 2005). Den synen impliceras i Bourdieus föreställning ovan om att demonstrationer är något som äger rum i konstituerandet av arbetarklassen. Pierre Rosanvallon (1998: 130) säger om representationen att den inte, tvärtemot vad det verkar, består av de sätt på vilka samhället och dess indelningar beskrivs, utan av de sätt på vilka "samhället produceras och en tolkning av det skisseras". Demonstrationen är definitivt en form av representation i den meningen: den producerar jämte andra former av aktion samhället genom att konstruera indelningar i det. 
Denna uppfattning förblir främmande för den finska synen, där demonstrationen stannar kvar i skuggan av den representativa politiken, antingen den drivs av politiska partier eller (andra) sammanslutningar (jfr Luhtakallio 20I2). Där intar, trots en viss ny flexibilitet, den direkta massaktionens högtalare fortfarande en underordnad position i förhållande till representanters möten vid ett förhandlingsbord och påverkas av det.

Översättning: Sven-Erik Torhell

\section{Referenser}

Agulhon, Maurice 1979. La République au village. Paris: Seuil.

Alapuro, Risto 2005. "Associations and Contention in France and Finland: Constructing the Society and Describing the Society". Scandinavian Political Studies 28, 377-399. DOI: https://doi.org/IO.IIII/j.I467-9477.2005.00137.x

Alapuro, Risto 2006. "The Construction of the Voter in Finland, c. 1860-1907". Redescriptions I0, 4I-64.

URL: http://redescriptions.fi/media/uploads/yearbooks/2006/Alapuro_o6.pdf (I november 2017)

Berger, John 1968. "The Nature of Mass Demonstrations". New Society 23 maj, 754-755.

Björklund, Ilkka-Christian I968. "Pari sanaa suomalaisesta poliisista". Ydin 2, I42.

von Bonsdorff, Johan 1986. Kun Vanha vallattiin. Helsingfors: Tammi.

Bourdieu, Pierre 1985. "The Social Space and the Genesis of Groups". Social Science Information 24, 195-220.

DOI: https://doi.org/IO.II77/05390I88502400200I

Carrez, Maurice 20Io. "Les manifestations sociales-démocrates pour le suffrage universel en Finlande comme moyen de propagande politique (1904-1908)", i Maurice Carrez \& Vincent Robert (red.), Visages de la manifestation en France et en Europe (XIXe-XXe siècle). Dijon: EUD, 53-7I.

Champagne, Patrick 1984. "La manifestation. La production de l'évenément politique". Actes de la recherche en sciences sociales 52-53, I9-4I.

DoI: https://doi.org/I0.3406/arss.I984.3329

Favre, Pierre 1990. "Manifester en France aujourd'hui", i Pierre Favre (red.), La manifestation. Paris: Presses de la Fondation nationale des sciences politiques, II-65.

Hamon, Hervé \& Patrick Rotman 1987. Génération, band I. Les années de rêve. Paris: Seuil.

Hannula, Risto 1968. "Väkivaltainen pasifismi?" Ydin 2, III, I35.

Hentilä, Jorma A. I970. "Tavoitteet ja toteutus”, i Mielenosoitukset ja poliisi 22.-26.6.I97o. Helsingfors: Otava, 25-38.

Hobsbawm, Eric 1983. "Introduction: Inventing Traditions", i Eric Hobsbawm \& Terence Ranger (red.), The Invention of Tradition. Cambridge: Cambridge University Press, I-I4. 
Hobsbawm, Eric 2002 [1983]. Massproducerade traditioner. Lund: Arkiv förlag (övers. av "Mass-Producing Traditions: Europe, I870-1914" ur Hobsbawm \& Ranger (red.), The Invention of Tradition).

Huxley, Steven Duncan 1990. Constitutionalist Insurgency in Finland. Finnish "Passive Resistance" against Russification as a Case of Nonmilitary Struggle in the European Resistance Tradition. Studia historica 38. Helsingfors: SHS.

Jussila, Osmo 1979. Nationalismi ja vallankumous venäläis-suomalaisissa subteissa I89919I4. Helsingfors: Suomen Historiallinen Seura.

Kirby, David 1988. "Folket och föreningarna" (bokrecension). Historisk Tidskrift för Finland 73, 64-70.

Klinge, Matti 1967a. Ylioppilaskunnan historia, vol. I. Porvoo och Helsingfors: WSOY.

Klinge, Matti 1967b. Ylioppilaskunnan historia, vol. 2. Porvoo och Helsingfors: WSOY.

Klinge, Matti 1968a. Ylioppilaskunnan historia, vol. 3. Porvoo och Helsingfors: WSOY.

Klinge, Matti 1968b. Ylioppilaskunnan historia, vol. 4. Porvoo och Helsingfors: WSOY.

Klinge, Matti m.fl. 1989. Helsingfors universitet 1640-1990, del 2, Kejserliga Alexandersuniversitetet I808-19I7. Helsingfors: Otava.

Lahtela, Markku 1967. "Täten eroan puolustuslaitoksesta". Ydin I, 87-88.

Lindström, Samu 20I2. "Kuokkavierasjuhlat ja kuokkavierasjulkisuus. Mielenosoitustapahtuman yhteiskunnallisia tulkintoja". Sosiologia 49, 32-46.

Luhtakallio, Eeva 20I2. Practicing Democracy. Local Activism and Politics in France and Finland. Basingstoke: Palgrave Macmillan.

Mielenosoitukset ja poliisi 22.-26.6.1970. 1970. Helsingfors: Otava.

Monet, Jean-Claude 1990. "Maintien de l'ordre ou création du désordre?", i Pierre Favre (red.), La manifestation. Paris: Presses de la Fondation nationale des sciences politiques, 229-268.

Monjardet, Dominique 1990. "Manifestation du côté du maintien de l'ordre", i Pierre Favre (red.), La manifestation. Paris: Presses de la Fondation nationale des sciences politiques, 207-228.

Mäkelä, Klaus 1967. ”Hyödyllinen väkivalta?” Ydin I, 88-89.

Parikka, Raimo 1987. "Paikallinen työläisyhteisö, työväenkulttuuri ja työväenliike", i Markku Hyrkkänen, Olli Vehviläinen \& Juha Hannikainen (red.), Väki voimakas, vol. 3, Näkökulmia työväen ammatilliseen ja paikalliseen historiaan. Tampere: Työväen historian ja tutkimuksen seura, II9-I5I.

Parikka, Raimo 1988a. "Työväenliikkeen vallan strategioista". Kommunisti 44, nr 8-9, 8-I4.

Parikka, Raimo 1988b. "Työväenliikkeen suhde valtioon". Kommunisti 44, nr Io, 24-28. Perrot, Michelle 1984a. "The First of May I890 in France: The Birth of a Working-Class Ritual", i Pat Thane, Geoffrey Crossick \& Roderick Floud (red.), The Power of the Past. Essays for Eric Hobsbawm. Cambridge: Cambridge University Press, I43-172.

Perrot, Michelle 1984b. Jeunesse de la grève. France 1871-I890. Paris: Seuil.

Perrot, Michelle 1986. "On the Formation of the French Working Class", i Ira Katznelson \& Aristide R. Zolberg (red.), Working-Class Formation. Nineteenth-Century Patterns in Western Europe and the United States. Princeton: Princeton University Press, 7I-IIO. 
Pirinen, Esko 1968. ”Johdatusta mielenosoituksen teoriaan”. Ydin 2, I08-I09, I34.

"Ranskan opetukset". 1968. Ydin 2, I07.

Rodriguez, Miguel I990. Le Ier mai. Paris: Gallimard, Julliard.

Rosanvallon, Pierre 1998. Le peuple introuvable. Histoire de la représentation démocratique en France. Paris: Gallimard.

Salkola, Marja-Leena 1985. Työväenkaartien synty ja kehitys punakaartiksi, volym I. Helsingfors: Valtioneuvoston kirjapaino.

Siltala, Juha 1985. Lapuan liike ja kyyditykset 1930. Helsingfors: Otava.

Soikkanen, Hannu I96I. Sosialismin tulo Suomeen. Ensimmäisiin yksikamarisen eduskunnan vaaleihin asti. Porvoo och Helsingfors: WSOY.

Soikkanen, Hannu i975. Kohti kansanvaltaa, vol. I. Vasa: Suomen sosialidemokraattinen puolue.

Stenius, Henrik 1977. "Järjestö-Suomen kehityspiirteitä”, i Matti Kuusi, Risto Alapuro \& Matti Klinge (red.), Maailmankuvan muutos tutkimuskohteena. Helsingfors: Otava, 77-97.

Stenius, Henrik 1980. "The Breakthrough of the Principle of Mass Organization in Finland". Scandinavian Journal of History 5, 197-217. DoI: https://doi.org/10.1080/03468758008578974

Sulkunen, Irma 1986. Raittius kansalaisuskontona. Raittiusliike ja järjestäytyminen I870-luvulta suurlakon jälkeisiin vuosiin. Helsingfors: Suomen Historiallinen Seura.

Suomela, Kalevi 1968. "Milloin mellakointi on oikeutettua?" Ydin 2, I43-I44.

Suppola, Salme 1973. Suomalainen mielenosoitus. Helsingfors: Oikeusministeriön lainsäädäntöosaston julkaisuja ıo.

Swidler, Anne 1986. "Culture in Action: Symbols and Strategies". American Sociological Review 5I, 273-286.

URL: http://www.jstor.org/stable/209552I

Taipale, Ilkka 1970. "Hiljaa - kun osoitatte mieltä”, i Mielenosoitukset ja poliisi 22.26.6.1970. Helsingfors: Otava, 7-24.

Therborn, Göran 1996. Europa, det moderna. Sambällen i öst och väst, nord och syd 19452000. Stockholm: Carlsson.

Therborn, Göran 20I4. "Klass i det tjugoförsta århundradet". Arkiv. Tidskrift för samhällsanalys 3, 67-97.

DOI: https://doi.org/I0.13068/2000-6217.3.3

Tikka, Marko 2009. Kun kansa leikki kuningasta. Suomen suuri lakko I905. Helsingfors: Suomalaisen Kirjallisuuden Seura.

Tilly, Charles 1978. From Mobilization to Revolution. Reading: Addison-Wesley.

Tilly, Charles 198I. "Introduction”, i Louise A. Tilly \& Charles Tilly (red.), Class Conflict and Collective Action. London: Sage, 13-25. 


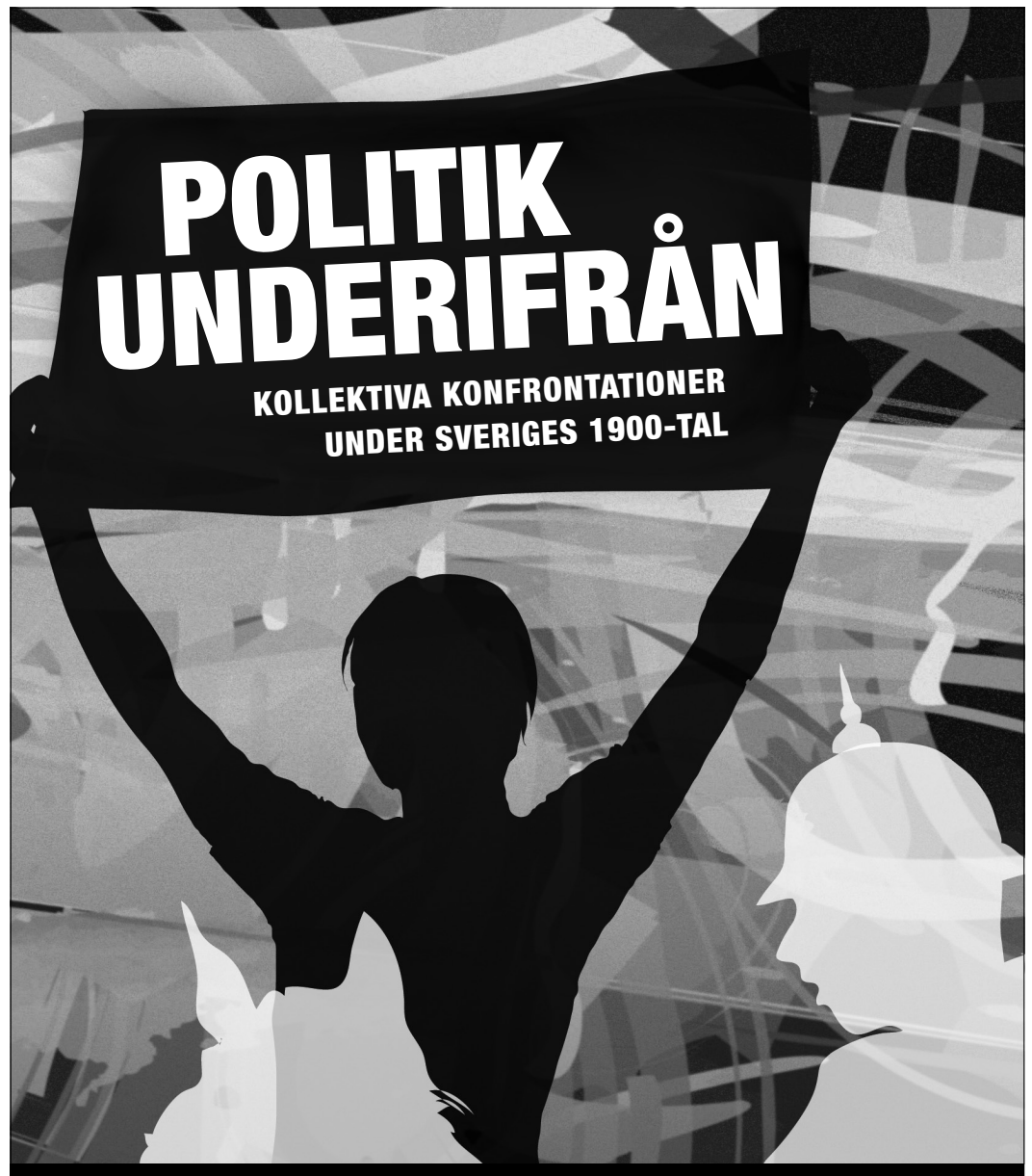

I POLIIK UWDERIFRÅN skriver historiker och samhällsvetare om politiska och sociala konflikter i 1900-talets Sverige då människor har brutit mot den dominerande politiska kulturens normer för hur man får göra politik och vilka som får delta i politiska processer. Från rösträttsstriden i början av seklet, över gatukravaller, vilda strejker och den gryende miljörörelsens kamp, till konflikter om vem som har rätt att använda det urbana rummet åren efter murens fall.

Andrés Brink Pinto \& Martin Ericsson (red.), Arkiv förlag, 216 sidor

\section{"LÄS MER OM BOKEN PÅ WWW-ARKIWWU:}



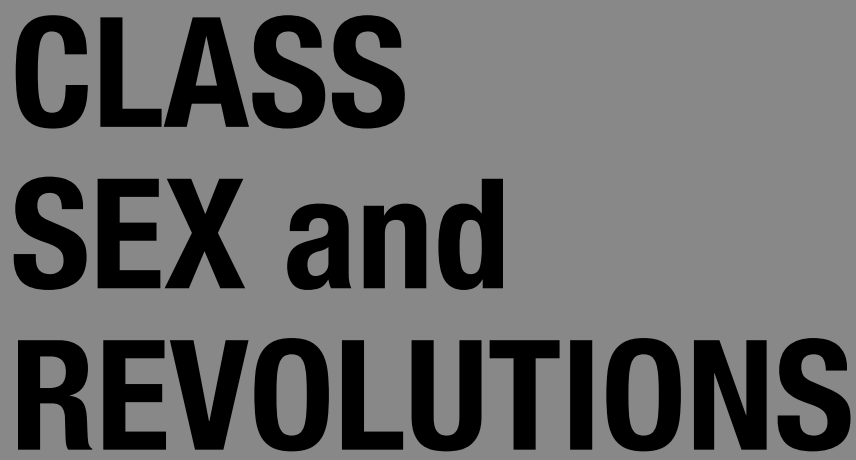

\section{Göran Therborn - a critical appraisal}

In between Science, Class and Society (1976) and The Killing Fields of Inequality (2013) Göran Therborn has consistently challenged received wisdom in politics and the social sciences. Today his work is spread across six continents, Latin America in particular, and has been translated into more than twenty languages.

This book is a critical appraisal of the themes Göran Therborn has pursued up till now, and is introduced by Robin Blackburn, for almost twenty years his editor at New Left Review. The book is edited by Gunnar Olofsson and Sven Hort.

Contributors include among others Risto Alapuro, Perry Anderson, Anita Göransson, Eric Hobsbawm, Habibul Haque Khondker, Åsa Cristina Laurell, Lena Lavinas, Bo Rothstein, Anders Stephanson, Immanuel Wallerstein, Karin Widerberg, Erik Olin Wright and Elisabeth Özdalga.

\section{ARKIV FÖRLAG, 436 pages}

